\title{
Response of hybrid maize to multiple soil organic amendments under sufficient or deficient soil zinc situation
}

\begin{abstract}
Naeem Sarwar ${ }^{1}$, Khuram Mubeen ${ }^{2}$, Allah Wasaya ${ }^{3}$, Atique-ur-Rehman ${ }^{1}$, Omer Farooq $^{1}$, Muhammad Shehzad ${ }^{4}$
${ }^{1}$ Department of Agronomy, Bahauddin Zakariya University, Multan, Pakistan

${ }^{2}$ Department of Agronomy, Muhammad Nawaz Sharif University of Agriculture, Multan, Pakistan

${ }^{3}$ College of Agriculture, Bahauddin Zakariya University, Bahadur Sub-Campus, Layyah, Pakistan

${ }^{4}$ Department of Agronomy, University of Poonch, Rawalakot, AJ\&K, Pakistan

\section{Abstract}

We studied the role of addition of various organic supplements for zinc uptake and overall maize crop performance. In field experiment, different sources of organic matter were added as supplement doses in the form of compost, biochar, humic acid and biofertilizer with or without soil zinc application. All other agronomic practices were remained normal as per farming community recommendation. Results revealed that various organic supplements significantly improved the crop performance not under zinc applied soil while also under zinc deficient soil. Crop showed accelerated growth in term of leaf area index, leaf area duration, crop growth rate etc which further leads toward better crop yield and quality. Organic supplements (biochar>compost>humic acid>biofertilizer) improve the crop production in zinc deficient as well as in zinc fertile soil but this effect was most prominent under biochar application. Findings suggest that farmers can enhance the maize crop productivity with the addition of organic supplements under zinc fertilization.
\end{abstract}

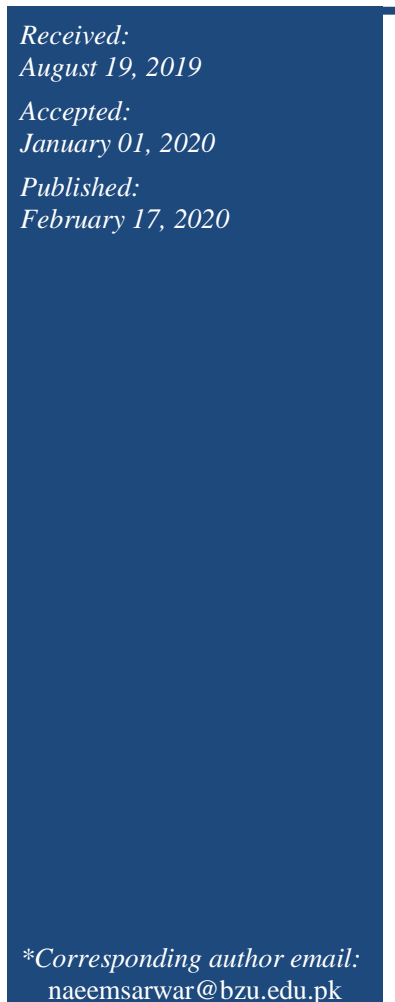

Keywords: Crop, Soil fertility, Organic supplements, Yield

\section{How to cite this:}

Sarwar N, Mubeen K, Wasaya A, Rehman AU, Farooq O and Shehzad M, 2020. Response of hybrid maize to multiple soil organic amendments under sufficient or deficient soil zinc situation. Asian J. Agric. Biol. 8(1):38-43.

DOI: $10.35495 / a j a b .2019 .07 .332$

This is an Open Access article distributed under the terms of the Creative Commons Attribution 3.0 License. (https://creativecommons.org/licenses/by/3.0), which permits unrestricted use, distribution, and reproduction in any medium, provided the original work is properly cited.

\section{Introduction}

Deficiency of essential micronutrients in human is the result of deficient staple food grown on less fertile soils. Zinc deficient soil, is not effecting crop growth but also reducing yield quality which is directly impacting the human health (Prasad, 2009). Zinc has basic role in cell growth, metabolism and differentiation process, so, its deficiency ultimately resulted in stunted growth, reduce disease resistance and enhanced mortality rates in Childs (Chaffee and King, 2012; Caulfield et al., 1998).

Zinc enrichment in food can be enhanced in different ways like food fortification, genetically modified crop and crop fertilization. Agronomic fortification seems an attractive and farmer feasible method to enhance zinc contents in plants or in edible plant portion. But, it also not found effective due to Fe soil insolubility. Organic fertilizers play a vital role in improving soil zinc availability (Tabassum et al., 
2014; Rathod et al., 2012). Various organic amendments can be used like farm yard manure, compost, biochar, biofertilizer and humic acid to improve soil health and fertility. Organic matter changes the physico-chemical properties of the soil which in turn improve the availability of zinc as per crop need. Furthermore, organic matter improves the microbial biomass which favours plant zinc uptake (Tejada et al., 2006; Liang et al., 2003). Tabassum et al., 2014 explained that press mud improve zinc uptake to plants which enhanced maize crop growth and yield as compared some other organic sources. Chowdhury et al. (2000) favoured the use of manure compost as he found higher soil organic carbon. Similarly, some other studies also highlights that use of organic amendments significantly improved the crop yield and soil organic carbon which is directly related to nutrients availability to plants (Das and Dkhar, 2011; Tu et al., 2006).

Soil zinc is present in different forms which are in state of dynamic equilibrium, while, labile zinc pool is directly dependent on these transformation of zinc forms (Mishra et al., 2009). Zinc deficiency is considered as secondary, caused by soil factors (Sharma and Chaudhary, 2007). Biochar is a pyrolysed organic waste which have shown promising agronomic effects in less fertile soil in different areas of world (Biederman and Harpole, 2013; Liu et al., 2013). Biochar is a rich carbon source which improves organic matter of soil but also improve soil physical, chemical and biological properties (Cornelissen et al., 2013; Glaser et al., 2002). Moreover, it enhance colonization of mycorrhizal fungi which ameliorate plants nutrient uptake process (Atkinson et al., 2010). It's the need of the time to diagnose and rectify the zinc deficiency to save major population. Keeping in view the role of organic fertilizers in direct or indirect availability of zinc, we designed experiment with supplement application of various available organic fertilizers to see that which organic source is most efficient.

\section{Material and Methods}

Filed experiment was conducted as research farm of Agronomy, Bahauddin Zakariya University, Multan. Seasonal maize crop season was followed for study i.e Mid July to Oct. Climate of this region is mostly semi-arid having some moon soon rainfall during this season. Experimental soil was silty clay having $\mathrm{pH}$ more than 7 and very less organic matter i.e $0.56 \%$.

\section{Crop husbandry}

Experimental field was selected at the agronomic farms and marked by making bunds all around the field. Rauni irrigation was applied about one week before soil preparation. After weeds emergence, soil was rotavated to mix all emergent weeds. After that, field was prepared by using sub-soiler as deep tillage implement following by cultivator and planking. After having good soil tilth, ridges were made in the field by using mechanical ridger drawn by tractor having distance of $75 \mathrm{~cm}$. then field was divided as per experimental treatments having plot size of $4 \mathrm{mx}$ $3 \mathrm{~m}$. P-1574 hybrid was purchased from the market. All seed was treated with fungicide with more than 95\% germination potential. There were two factors, first factor with sufficient or without zinc application. In second factor, Treatments were: $T_{1}$ : Compost, $T_{2}$ : Humic acid, $\mathrm{T}_{3}$ : Biochar and $\mathrm{T} 4$ : Plant growth promoting rhizobia along with control treatment $\mathrm{T}_{0}$. All inorganic fertilizer (140: 80:60 NPK) as well as organic supplements were applied at the time of soil preparation. Nitrogen fertilizer was split in three equal doses, one at the time of sowing while other two doses were applied at three and six leaf stage. Crop was sown manually keeping distant of $25 \mathrm{~cm}$ plant to plant. Treatments were arranged following randomized complete block design with split plot. Irrigation water was applied as per crop need. Moreover, crop was managed weeds free as well as insect free by adopting different strategies. Weeds were uprooted manually, while the root borer or top borer were controlled by applying furadon at critical attack stage. During crop growth, plants were also harvested manually for growth analysis. Crop was harvested manually when cobs reached at full maturity stage.

\section{Statistical analysis}

Collected data was analyzed by using statistics software and ANOVA was generated to see the significance of all treatments. Difference among various treatment means were compared by LSD test at $5 \%$ probability level.

\section{Results}

\section{Growth parameters}

Crop growth response was varied under zinc applied 
soil as well as in zinc deficient soil. Various organic supplements significantly improved the crop growth not under zinc applied soil while also under zinc deficient soil. Leaf area index is very important for optimum growth which ultimately directed toward good crop yield. Trend explained that leaf area index increased positively from seedling stage and reached at its maximum level at highest growth stage while sharp decline was observed when crop moved toward maturity (Fig-1).

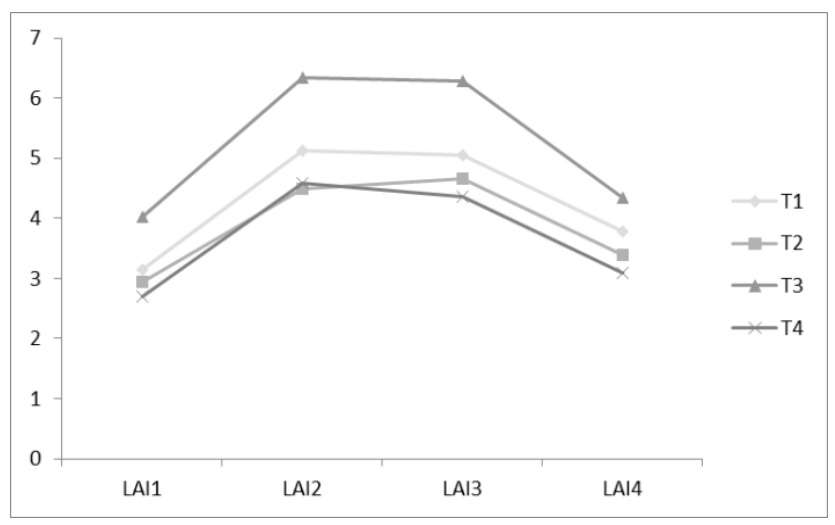

Figure-1: Response of leaf area index to different organic supplements

Table data showed that highest leaf area index was obtained under biochar $\left(\mathrm{T}_{3}\right)$ applications along with basal dose of zinc application $\left(\mathrm{T}_{3} \mathrm{Zn}_{1}\right)$, while minimum leaf area index was attained by the plants that were grown under control $\left(\mathrm{T}_{0)}\right.$ conditions without zinc application.

Table-1: Effects of organic supplements on growth attributes of maize hybrid under sufficient and scarce zinc application

\begin{tabular}{|c|c|c|c|c|}
\hline Treatments & LAI & $\begin{array}{c}\text { LAD } \\
(\mathbf{g} / \mathbf{m} \mathbf{2} / \mathbf{d a y})\end{array}$ & $\begin{array}{c}\text { TDM } \\
(\mathbf{g})\end{array}$ & $\begin{array}{c}\text { CGR } \\
(\mathbf{g} / \mathbf{m} \mathbf{2} / \mathbf{d a y})\end{array}$ \\
\hline $\mathrm{T}_{0} \mathrm{Zn}_{0}$ & $3.2 \mathrm{~h}$ & $190 \mathrm{~g}$ & $2988 \mathrm{j}$ & $61 \mathrm{~h}$ \\
\hline $\mathrm{T}_{1} \mathrm{Zn}_{0}$ & $5.0 \mathrm{c}$ & $264 \mathrm{~d}$ & $3558 \mathrm{f}$ & $70 \mathrm{de}$ \\
\hline $\mathrm{T}_{2} \mathrm{Zn}_{0}$ & $4.3 \mathrm{e}$ & $237 \mathrm{e}$ & $3534 \mathrm{~g}$ & $74 \mathrm{e}$ \\
\hline $\mathrm{T}_{3} \mathrm{Zn}_{0}$ & $5.3 \mathrm{~b}$ & $311 \mathrm{~b}$ & $3582 \mathrm{e}$ & $82 \mathrm{~d}$ \\
\hline $\mathrm{T}_{4} Z_{0}$ & $4.0 \mathrm{f}$ & $220 \mathrm{f}$ & $3515 \mathrm{~h}$ & $70 \mathrm{f}$ \\
\hline $\mathrm{T}_{0} Z_{1}$ & $3.6 \mathrm{~g}$ & $193 \mathrm{~h}$ & $3024 \mathrm{i}$ & $63 \mathrm{~g}$ \\
\hline $\mathrm{T}_{1} Z_{1} n_{1}$ & $5.3 \mathrm{~b}$ & $280 \mathrm{c}$ & $3752 \mathrm{~b}$ & $97 \mathrm{~b}$ \\
\hline $\mathrm{T}_{2} Z_{1}$ & $4.7 \mathrm{~d}$ & $258 \mathrm{~d}$ & $3730 \mathrm{c}$ & $76 \mathrm{c}$ \\
\hline $\mathrm{T}_{3} Z_{1}$ & $6.0 \mathrm{a}$ & $354 \mathrm{a}$ & $3769 \mathrm{a}$ & $101 \mathrm{a}$ \\
\hline $\mathrm{T}_{4} \mathrm{Zn}_{1}$ & $5.2 \mathrm{c}$ & $259 \mathrm{~d}$ & $3714 \mathrm{~d}$ & $86 \mathrm{~d}$ \\
\hline & 0.5 & 42.1 & 16.5 & 3.42 \\
\hline
\end{tabular}

$\mathrm{T}_{0}$ : no application, $\mathrm{T}_{1}$ : Compost, $\mathrm{T}_{2}$ : Humic Acid, $\mathrm{T}_{3}$ : Biochar, $\mathrm{T}_{4}$ : PGPRs, $\mathrm{Zn}_{1}$ : with zinc application, $\mathrm{Zn}_{0}$ : without zinc application
It is also transparent that maximum LAD was recorded under the results where biochar $\left(\mathrm{T}_{3}\right)$ was supplemented along with zinc application while unsatisfactory results were produced under control conditions where no external supplements $\left(\mathrm{T}_{0}\right)$ as well as zinc incorporated.

Similarly, crop attained highest total dry matter (TDM) under biochar supplementation in zinc applied soil while lowest TDM was achieved with no external supplement $\left(\mathrm{T}_{0}\right)$ and zinc application. Crop growth rate was also found to be in line with already discussed growth parameters as value of $T_{3} Z_{1}$ was prominent in this case which highlighted the importance of this treatment combination (Table-1).

\section{Yield parameters}

There was very clear difference was recorded between organic supplements under zinc fertile soil and in zinc deficient soil. All organic supplements significantly enhanced various yield attributing factors as compared with control plants while zinc fertilizer further enhanced this positive impact on maize crop.

Table-2: Response of various yields attributes of maize hybrid to organic supplements under sufficient and scarce zinc application

\begin{tabular}{|c|c|c|c|c|c|}
\hline Treatments & $\begin{array}{c}\text { Cobs } \\
\text { Length } \\
(\mathbf{c m})\end{array}$ & grains/cob & $\begin{array}{c}\text { 1000 Grain } \\
\text { Weight }(\mathbf{g})\end{array}$ & $\begin{array}{c}\text { Biological } \\
\text { Yield } \\
(\mathbf{t} / \mathbf{h a}-1)\end{array}$ & $\begin{array}{c}\text { Grain } \\
\text { yield } \\
(\mathbf{k g} / \mathbf{h a}-1)\end{array}$ \\
\hline $\mathrm{T}_{0} \mathrm{Zn}_{0}$ & $11.1 \mathrm{e}$ & $378 \mathrm{f}$ & $229 \mathrm{f}$ & $54 \mathrm{i}$ & $6634 \mathrm{~g}$ \\
\hline $\mathrm{T}_{1} \mathrm{Zn}_{0}$ & $15.0 \mathrm{c}$ & $431 \mathrm{c}$ & $261 \mathrm{c}$ & $64.7 \mathrm{e}$ & $7016 \mathrm{~cd}$ \\
\hline $\mathrm{T}_{2} \mathrm{Zn}_{0}$ & $13.7 \mathrm{~d}$ & $426 \mathrm{cb}$ & $257 \mathrm{dc}$ & $62.6 \mathrm{f}$ & $6975 \mathrm{~d}$ \\
\hline $\mathrm{T}_{3} \mathrm{Zn}_{0}$ & $17.0 \mathrm{ab}$ & $437 \mathrm{~b}$ & $265 \mathrm{cb}$ & $66.9 \mathrm{~cd}$ & $7083 \mathrm{c}$ \\
\hline $\mathrm{T}_{4} \mathrm{Zn}_{0}$ & $13.0 \mathrm{~d}$ & $421 \mathrm{~cd}$ & $252 \mathrm{ed}$ & $60.6 \mathrm{~g}$ & $6933 \mathrm{ed}$ \\
\hline $\mathrm{T}_{0} \mathrm{Zn}_{1}$ & $11.8 \mathrm{ef}$ & $395 \mathrm{de}$ & $234 \mathrm{f}$ & $55.6 \mathrm{~h}$ & $6743 \mathrm{ef}$ \\
\hline $\mathrm{T}_{1} \mathrm{Zn}_{1}$ & $16.3 \mathrm{~b}$ & $452 \mathrm{a}$ & $273 \mathrm{a}$ & $70.0 \mathrm{~b}$ & $7169 \mathrm{a}$ \\
\hline $\mathrm{T}_{2} \mathrm{Zn}_{1}$ & $15.0 \mathrm{c}$ & $442 \mathrm{~b}$ & $269 \mathrm{ab}$ & $67.8 \mathrm{c}$ & $7122 \mathrm{~b}$ \\
\hline $\mathrm{T}_{3} \mathrm{Zn}_{1}$ & $18.0 \mathrm{a}$ & $461 \mathrm{a}$ & $277 \mathrm{a}$ & $73.3 \mathrm{a}$ & $7219 \mathrm{a}$ \\
\hline $\mathrm{T}_{4} \mathrm{Zn}_{1}$ & $13.7 \mathrm{~d}$ & $434 \mathrm{~b}$ & $261 \mathrm{c}$ & $65.8 \mathrm{de}$ & $7075 \mathrm{c}$ \\
\hline $\mathrm{LSD}_{0.05}$ & 1.5 & 9 & 5.3 & 3.3 & 40.22 \\
\hline
\end{tabular}

$\mathrm{T}_{0}$ : no application, $\mathrm{T}_{1}$ : Compost, $\mathrm{T}_{2}$ : Humic Acid, $\mathrm{T}_{3}$ : Biochar, $\mathrm{T}_{4}$ : PGPRs, $\mathrm{Zn}_{1}$ : with zinc application, $\mathrm{Zn}_{0}$ : without zinc application

Data showed that longer cobs $(18 \mathrm{~cm})$ were achieved with biochar application in sufficient soil zinc while the shorter cobs $(11.1 \mathrm{~cm})$ were noted in control condition where no addition of organic supplement was made. Cob length under treatment combination of $\mathrm{T}_{3} \mathrm{Zn}_{0}$ was also found statistically similar with 
$\mathrm{T}_{3} \mathrm{Zn}_{1}$ but numerically cob length under zinc application was found longer. Grains per cob were also found higher in treatments of $\mathrm{T}_{3} \mathrm{Zn}_{1}$ (461) and $\mathrm{T}_{1} \mathrm{Zn}_{1}$ (452) where we applied biochar and compost in zinc fertilized soil.

Further analysis of data table also highlighted that heavier grains were recorded in treatment combination of $\mathrm{T}_{3} \mathrm{Zn}_{1}(277 \mathrm{~g})$ which was further at par with $\mathrm{T}_{1} \mathrm{Zn}_{1}(273 \mathrm{~g})$ and $\mathrm{T}_{2} \mathrm{Zn}_{1}(269 \mathrm{~g})$ which showed the importance of organic supplement as biochar>compost>humic acid. In case of biological yield, it was very clear that biochar application under zinc fertile soil $\left(\mathrm{T}_{3} \mathrm{Zn}_{1}\right)$ significantly increased the biological yield while all other treatments were found inferior. Grain yield is the cumulative response of all different factors including growth and yield which is also most important. Treatment comparison reveals that $\mathrm{T}_{3} \mathrm{Zn}_{1}(7219 \mathrm{~kg} / \mathrm{ha})$ and $\mathrm{T}_{1} \mathrm{Zn}_{1}(7169 \mathrm{~kg} / \mathrm{ha})$ was found superior as compared with all other treatments while numerically biochar was superior as compared with compost (biocahr>compost) while in presence of zinc fertilization (Table-2).

\section{Grain-Zn uptake}

No doubt organic supplements provided very suitable conditions in enhancing the bioavailability of zinc for the plants and ultimately to the consumers of the grains. But most optimum results were obtained under the application of biochar where maximum uptake of zinc was observed while similar results are obtained under the application of compost. However, minimum uptake is observed under no external supplements (Fig 2).

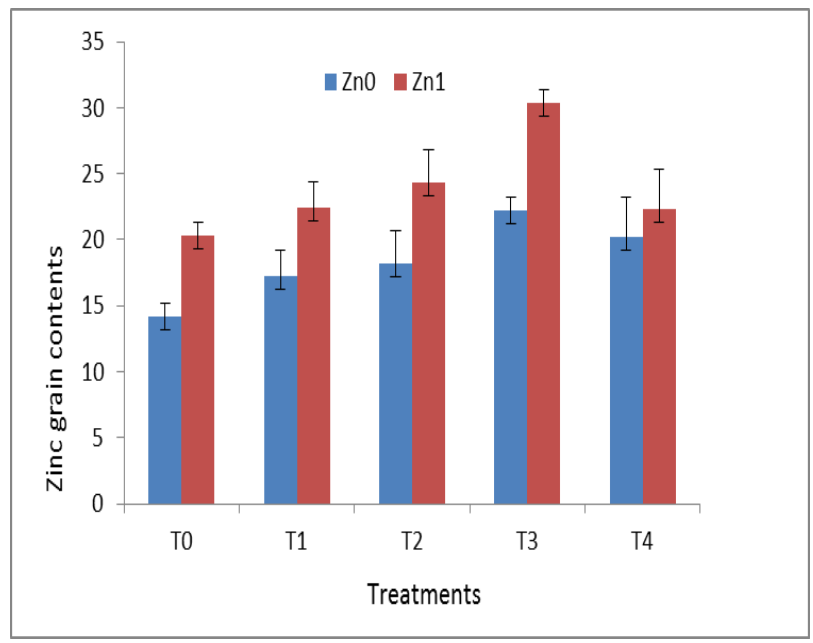
Figure-2: Grain-zinc contents under organic
supplementation to hybrid maize

\section{Discussion}

Experiment depicted that all growth and yield attributes were significantly improved at treatment interaction $\mathrm{T}_{3} \mathrm{Zn}_{1}$ under zinc applied soil with addition of biochar. In some cases compost and humic acid also performed in line with the biochar which overall represented the importance of organic amendments for zinc availability as well as for crop yield. Organic manure not only improve the zinc availability but also enhance the soil microbial activity (Rathod et al., 2012). Tabassum et al (2014), also explained that organic supplements offers a useful approach for zinc bioavailability in rice and chickpea crops. Zinc is present in soil in different forms like exchangeable, adsorbed, soil solution etc. rate of transformation of these different forms determined the size of zinc in labile pool which is also dependent on soil organic matter (Mishra et al., 2009). Crop showed its accelerated growth under organic supplements, not only in zinc applied soil while also in zinc deficient soil. It might me due to easily availability of various nutrients in root zone as organic matter provides binding force for soil nutrients. Furthermore, zinc is very important micronutrient and most of the soil of Pakistan is deficient in zinc so its availability to crop plants will ultimately improve the crop performance.

Different sources of organic matters can be use in the soil like farm yard manure, compost, humic acid as well as in recent years biochar. Biochar not only act as organic matter in soil but also a source of carbon sequestration. In developing countries like Pakistan, biochar seems a big solution for organic waste as it will minimize the big heaps of wastes in many areas. Positive impact of biochar have been documented in vide range of latitudes under less fertile soils (Liu et al., 2013; Cornelissen et al., 2013). Moreover, biochar application in soil also improve the soil biology by improving microbes activity, ameliorating nutrient uptake and enhances root -fungal association (Atkinson et al., 2010; Yamato et al., 2006). Most of the soil in the country is less fertile just because of higher input rates as well as due to the higher cropping intensity. In our experiment, biochar application resulted in excellent performance as compared to other organic sources. It might be due to having more positive impact of biochar application in less fertile soils. Pandit et al. (2018) revealed that nutrient stressed soil $(+363 \%)$ responded positively to biochar application as compared to nutrient abundant 
$(+132 \%)$. Experimental findings suggest that zinc organic matter is very important for crop production which should be applied in soil. Its application is more important in Pakistan as our soil is usually organic matter deficient. Burning of crop residues is common farming practice in the country, which not only wastes the nutrients but also pollute the environment. Farmer can mix these crop residues in the soil for organic matter supplements which not only improve crop productivity but may also reduce input cost. Furthermore, formation of compost and biochar are another sector which can reduce the big plant and animal waste to provide a rich organic matter sources for farming community. Moreover, these organic matter sources can also enriched with addition of some deficient soil nutrients for sustainable crop productivity.

\section{Conclusion}

Organic supplements (biochar $>$ compost $>$ humic acid>biofertilizer) improve the crop production in zinc deficient as well as in zinc fertile soil but this effect was most prominent under biochar application. Hybrid maize is exhaustive crop which needs continuous availability of nutrients so organic supplementation may bind nutrients, reduce losses and provide opportunity for sustainable maize crop production.

\section{Disclaimer: None.}

Conflict of Interest: None.

Source of Funding: None.

\section{References}

Atkinson CJ, Fitzgerald JD and Hipps NA, 2010. Potential mechanisms for achieving agricultural benefits from biochar application to temperate soils: a review. Plant Soil. 337: 1-18.

Biederman LA and Harpole WS, 2013. Biochar and its effects on plant productivity and nutrient cycling: a meta-analysis. GCB Bioenergy. 5: 202214.

Caulfield LE, Zavaleta N, Shankar AH and Merialdi M, 1998. Potential contribution of maternal zinc supplementation during pregnancy to maternal and child survival. Am. J. Clinic. Nutr. 68: 499S508 S.

Chaffee BW and King JC, 2012. Effect of zinc supplementation on pregnancy and infant outcomes: a systematic review. Paed. Perinatal Epid. 26:118-137.

Chowdhury MAH, Kouno K, Ando T and Nagaoka T, 2000. Microbial biomass, S mineralization and $S$ uptake by African millet from soil amended with various composts. Soil Biol. Biochem. 32: 845-852

Cornelissen G, Martinsen V, Shitumbanuma V, Alling V, Breedveld GD, Rutherford DW, Sparrevik M, Hale SE, Obia A and Mulder J, 2013. Biochar effect on maize yield and soil characteristics in five conservation farming sites in Zambia. Agron. 3: 256-274.

Das BB and Dkhar MS, 2011. Rhizosphere microbial populations and physico chemical properties as affected by organic and inorganic farming practices. Am. Euras. J. Agric. Environ. 10: 140150

Glaser B, Lehmann J and Zech W, 2002. Ameliorating physical and chemical properties of highly weathered soils in the tropics with charcoal-a review. Biol. Fertil. Soils. 35: 219230.

Liang YC, Chen Q, Liu Q, Zhang WH and Ding RX, 2003. Exogenous silicon ( $\mathrm{Si}$ ) increases antioxidant enzyme activity and reduces lipid peroxidation in roots of salt stressed barley (Hordeum vulgare L.). J. Plant Physiol. 160: 1157-1164

Liu X, Zhang A, Ji C, Joseph S, Bian R, Li L, Pan G and Paz-Ferreiro J, 2013. Biochar's effect on crop productivity and the dependence on experimental conditions - a meta analysis of literature data. Plant Soil. 373: 583-594.

Mishra P, Singh R, Shrivastava PC and Ram B, 2009. Effect of continuous cropping and fertilization on Zinc fractions and their contribution to plant uptake under rice-wheat system. J. Ind. Society Soil Sci. 57: 167-171.

Pandit NR, Jan M, Sarah EH, Vegard M, Hans PS and Gerard C, 2018. Biochar improves maize growth by alleviation of nutrient stress in a moderately acidic low-input Nepalese soil. Sci. Total Environ. 625: 1380-1389.

Prasad AS, 2009. Zinc: role in immunity, oxidative stress and chronic inflammation. Curr. Opin. Clin. Nutr. Metab. Care. 12: 646-52.

Rathod DD, Meena MC and Patel KP, 2012. Evaluation of different zinc-enriched organics as source of zinc under wheat- maize (fodder) cropping sequence on zinc- deficient Typic Haplustepts. J. Ind. Society Soil Sci. 60: 50-56. 
Sharma JC and Chaudhary SK, 2007. Vertical Distribution of micronutrient cations in relation to soil characteristics in Lower Shiwaliks of Solan District in North-West Himalayas. J. Ind. Society Soil Sci. 55: 40-44.

Tabassum S, Sabha J, Ratan K, Dev CM, Pramod K and Rehana, 2014. Effect of Organic Manure and Zinc Fertilization on Zinc Transformation and Biofortification of Crops in Vertisols of Central India. J. Agric. Sci. 6: 221-231.

Tejada M, Hernandez MT and Garcia C, 2006. Application of two organic amendments on soil restoration: Effects on the soil biological properties. J. Environ. Qual. 35: 1010-1017

Tu C, Ristaino JB and $\mathrm{Hu}$ S, 2006. Soil microbial biomass and activity in organic tomato farming systems: Effects of organic inputs and straw mulching. Soil Biol. Biochem. 38: 247-255.
Yamato M, Okimori Y, Wibowo IF, Anshori S and Ogawa M, 2006. Effects of the application of charred bark of Acacia mangium on the yield of maize, cowpea and peanut, and soil chemical properties in South Sumatra, Indonesia. Soil Sci. Plant Nutr. 52: 489-495.

\section{Contribution of Authors}

Sarwar N: Designed experiment and collected data

Mubeen K: Helped in field experiment

Wasaya A: Statistical analysis and data interpretation

Rehman AU: Prepared initial draft of manuscript Farooq O: Edited and approved final manuscript Shehzad M: Helped in data collection 